\title{
Kent Sağlığı ve Covid-19 Kapsamında Sağlık Hizmetleri Mekansal Yer Seçiminin Değerlendirilmesi: Ankara Çankaya İlçesi Örneği*
}

Emine Şeyda Satılmış ${ }^{1}$

ORCID: 0000-0002-2573-2318

\author{
İrem Akkaya \\ Büyükcivelek ${ }^{2}$ \\ ORCID: 0000-0003-2840-0578
}

Çiğdem $\mathrm{Varol}^{3}$

ORCID: 0000-0002-2432-5745

\section{Öz}

Yeni Koronavirüs Hastalı̆̆ı (Covıd-19), ilk olarak Çin'in Wuhan Eyaleti'nde 2019 yılı Aralık ayının sonlarında ortaya çıkmış ve Ocak 2020'den itibaren tüm dünyaya yayılmıştır. Salgının küresel boyutta ciddi bir hal almasıyla, 11 Mart 2020'de Dünya Sağlık Örgütü (DSÖ) tarafından pandemi ilan edilmiştir. Covid-19'un küresel boyuta ulaşması dünyadaki tüm nüfusu tehdit etmeye başlamıştır. Salgın hastalıkların yayılmasında kentler şüphesiz büyük bir öneme sahipken aynı zamanda bulaşıcı hastalıkların yayılmasını durdurmak ve nüfus sağlı̆̆ını iyileştirmek için de çözümler sunan yerlerdir. Günümüzde kent sağlı̆̆ı yaklaşımının üç temel odak noktasından biri olan hizmetlerin kentsel mekândaki sunumu, Covid-19 ile beraber önem kazanmıştır. Bu dönemde koruyucu, tedavi ve rehabilite edici sağhlk hizmetlerine ihtiyaç artmış ve sağlık hizmetlerinin yetersizliği gündeme gelmiştir. Bu çalışma, Ankara ili Çankaya ilçesindeki sağlık hizmetlerine yönelik mekânsal kararları irdeleyerek yasal kapsamda belirlenen standartlara uygunluğunu ve erişilebilirliğini tespit ederek pandemi döneminde să̆llk hizmet sunumunu tartışmayı amaçlamaktadır. Bu amaç doğrultusunda Ankara ili Çankaya ilçesindeki yer alan sağhlk hizmet alanlarının mekânsal yer seçimi kararlarına yönelik, ilgili kurum ve kuruluşlardan elde edilen veriler doğrultusunda; konum, alan büyüğ̈̈ ve kapasite tespiti yapılmıştır. Coğrafi bilgi sistemleri aracılı̆̆ılyla yapılan analizlerde, să̆glk hizmetlerinin konum, standartlara uyum ve erişilebilirlik düzeylerinin, Covid-19 mekansal yayılımı da göz önünde bulundurularak, uzun erimde hizmet ihtiyacı ve sunumuna vereceği cevap sorgulanmıştır.

Anahtar Kelimeler: Kent Sağlı̆̆ı, Sağlık Hizmetleri, Mekansal Yerseçimi, Erişilebilirlik, Covid-19, Ankara-Çankaya

\footnotetext{
* Bu makale çalışması “5.Kent Araştırmaları Kongresi”nde bidiri olarak sunulmuştur.

${ }^{1}$ Gazi Üniversitesi, E-mail: emineseydaa@gmail.com

${ }^{2}$ Gazi Üniversitesi, Çankaya Belediyesi, E-mail: akkayairem@gmail.com

${ }^{3}$ Prof. Dr., Gazi Üniversitesi, E-mail: cvarol@gazi.edu.tr

idealkent @ Kent Araştırmaları Dergisi (Journal of Urban Studies)

http://idealkentdergisi.com

Geliş Tarihi Received Date: 21.12.2020 Kabul Tarihi Accepted Date: 16.04.2021
} 


\title{
Assessment of Spatial Location of Health Care Services of Urban Health and Covid-19: The Case of Ankara-Çankaya District
}

$*$

\author{
Emine Şeyda Satılmış ${ }^{4}$ \\ ORCID: 0000-0002-2573-2318
}

İrem Akkaya

Büyükcivelek ${ }^{5}$

ORCID: 0000-0003-2840-0578
Çiğdem Varol 6

ORCID: 0000-0002-2432-5745

\begin{abstract}
The New Coronavirus Disease (Covid-19) first appeared in Wuhan Province, China in late December 2019 and had spread all over the world since January 2020. As the epidemic became serious on a global scale, a pandemic was declared by the World Health Organization (WHO) on March 11, 2020. Covid-19's reaching a global level has become threatening the entire population in the world. While cities are the main sources in the spread of epidemics, they are also the places that offer solutions to prevent the spread of infectious diseases and to improve the health of the population. Nowadays, the delivery of services, which is one of the three main focal points of the urban health approach, has gained importance with Covid-19 in urban areas. In this period, the need for preventive, curative and rehabilitative personal health services has increased and the insufficiency of primary health care services has become to the agenda. This study aims to discuss the provision of health services during the pandemic period by examining the spatial location decisions of health services in Çankaya district of Ankara, determining the spatial standards and accessibility within the legal scope. For this purpose, the location, size and capacity of health service areas in Çankaya district of Ankara were determined by the data obtained from the relevant institutions and organizations for the spatial location selection decisions of the health service areas in Çankaya district of Ankara. In the analysis by using geographic information systems, the levels of the response of the health services' location, compliance with standards and accessibility was questioned in the long-term service need and delivery, taking into account of the spatial spread of Covid-19.
\end{abstract}

Keywords: Urban Health, Health Services, Spatial Location, Accessibility, Covid-19, Ankara-Çankaya

\footnotetext{
${ }^{4}$ Gazi Üniversitesi, E-mail: emineseydaa@gmail.com

${ }^{5}$ Gazi Üniversitesi, Çankaya Belediyesi, E-mail: akkayairem@gmail.com

${ }^{6}$ Prof. Dr., Gazi Üniversitesi, E-mail: cvarol@gazi.edu.tr

idealkent @ Kent Araştırmaları Dergisi (Journal of Urban Studies)

http://idealkentdergisi.com
}

Geliş Tarihi Received Date: 21.12.2020 Kabul Tarihi Accepted Date: 16.04.2021 


\section{Giriş}

Sağlık hakkı, uluslararası sözleşmeler ve ulusal mevzuat bağlamında koruma altına alınmış temel hak ve özgürlükler arasında yer almaktadır. Birleşmiş Milletler (BM) Ekonomik, Sosyal ve Kültürel Haklar Sözleşmesi'nin 12. Maddesi, "çevresel ve sınai sağlık şartlarının her yönüyle iyileştirilmesi, salgın, yöresel, mesleki ve diğer hastalıkların önlenmesi, tedavisi ve kontrolü ile hastalık durumunda herkese tıbbi hizmet ve tıbbi bakım sağlanması için gerekli şartların oluşturulması" hükmüyle Sözleşmeye taraf devletlere sorumluluklar yüklemektedir.

Kentleşme, geçen yüzyılda ve yeni yüzyılda dünya çapında tek ve en önemli demografik değişimdir. Son birkaç yıldır dünya nüfusunun çoğunun nasıl yaşadığına göre göze çarpan bir değişikliği temsil eder (Galea ve Vlahov, 2005, s. 1). Artan kentleşme ve gelişen teknolojiler ile beraber insanların karşılaştığı sağlık sorunlarını anlamak, insan sağlığını iyileştirmek önem kazanmaktadır. Yerel düzeydeki halk sağlığı kapasitelerinin değerlendirilmesi, sağlık güvenliği tehditlerine hazırlıklı olma, bu tehditlerin tespiti ve yanıtını etkileyebilecek güçlü ve zayıf yönlerin belirlenmesi önemli bir süreçtir (Boyce ve Katz, 2020). Kentsel alanda yetebilen ve talepleri karşılayabilen sağlık altyapısının varlığı ise olağanüstü durum karşısında kentleri dayanıklı hale getirmektedir.

Bulunduğumuz yüzyıl içerisinde Ebola, SARS, MERS gibi birçok salgın hastalık ortaya çıkmıştır. 2020 yılında ortaya çıkan ve uluslararası sınırları aşarak dünya çapında çok sayıda insanı etkileyen bir salgın (Kelly, 2011) haline dönüşen Covid-19 ile birlikte, kent sağlığı yaklaşımının üç temel odak noktasından biri olan hizmetlerin kentsel mekândaki sunumu önem kazanmıştır. Sağlık tesislerinin günlük hâlihazırlardaki hasta yüküne ek olarak hızlı bir şekilde artan Covid-19 kaynaklı vakaların varlı̆̆ bu dönemde kişiye yönelik koruyucu, tedavi ve rehabilite edici sağlık hizmetlerine talebi artırmış ve küresel olarak sağlık hizmetlerinin yetersizliği gündeme gelmiştir.

Bu kapsamda çalışmanın amacl; Ankara ili Çankaya ilçesinde yer alan ve planlanan sağlık hizmetlerine yönelik mekânsal kararları irdeleyerek yasal kapsamda belirlenen standartlara uygunluğunu ve erişilebilirliğini tespit ederek pandemi döneminde sağlık hizmet sunumunu tartışmaktır. Bu çalışma, çeşitli kademelerdeki sağlık hizmetleri sunumu, hizmet alanı erişimi ve Covid19 mekansal yayılımı kapsamında yapılacak karşılaştırmalarla hizmet yeterliliği, hizmet sunumuna yönelik olası strateji ve politikaların neler olabileceğini tanımlaması açısından önemlidir. 
Çalışma beş bölümden oluşmaktadır. İlk bölümde, kent sağlığı yaklaşımına ilişkin kuramsal çerçeve çizilmiştir. İkinci bölümde, Covid-19 ve kent sağllğ ilişkisi ele alınmıştır. Üçüncü bölümde, Türkiye'deki sağlık hizmetleri sunumu incelenmiştir. Dördüncü bölümde ise, çalışmanın yöntemi ve Ankara İli Çankaya İlçesinde yer alan sağlık hizmet alanlarının mekânsal yer seçimi kararları çeşitli boyutlarıyla analiz edilerek elde edilen bulgular ortaya konulmuştur. Beşinci ve son bölümde ise sonuç ve genel değerlendirmeler yapılmıştır.

\section{Kent Sağlığı Yaklaşımı}

Dünya Sağlık Örgütü (DSÖ)'ne göre kentleşme 21. yüzyılda sağlık üzerinde önemli etkiye sahip küresel trendlerden biridir. Dünya nüfusunun \%55'inden fazlasının kentsel alanlarda yaşaması kentleri sağlık ve refahın sağlandığı merkezi alanlara dönüştürmektedir. Ancak kentsel alandaki yetersiz barınma ve ulaşım, atık yönetimi, gürültü kirliliği, su kirliliği, hava kirliliği, kentsel ısı adaları, iklim değişikliği salgın hastalıklar, vb. birçok sorun bugünün ve yarının kentlerini büyük bir sağlık yüküyle karşı karşıya bırakmaktadır (World Health Organization urban health, 2020). Artan kentleşme ile beraber kentlerin bugün ve gelecekte karşılaşacağı sağlık sorunlara yönelik tespitler yapıp çözüm üretmek amacıyla ortaya çıkan çeşitli yaklaşımlar, politikalar ve kavramlardan biri de kent sağlığıdır.

Kent sağlığı, 1980'lerin ortalarında uluslararası halk sağlığının bir alt disiplini olarak ortaya çıkmıştır. 1980'lerden 1990'lara kadar mevcut halk sağlığı sistemlerine getirdiği farklı yaklaşımlar ve çözümlerle "yeni halk sağlığı" olarak adlandırılmıştır. (Harpham ve Molyneux, 2001). 1990'lardan günümüze kadar DSÖ'nün geliştirdiği politikalar ve uygulamalar ile kentsel sağlık yaklaşımı çalışma alanı olmuştur. Çok disiplinli bir çalışma alanı olan kentsel sağlık, en geniş anlamıyla kentsel nüfusun sağlığının incelenmesi anlamına gelmekte ve araştırması-uygulaması açısından karmaşık bir yapıya sahiptir (Galea ve Vlahov, 2005).

Kent sağlığı yaklaşımı, önemli görülen hastalıklar ve bu hastalıkların nüfus üzerinde yarattığı riske yöneliktir. Bu yaklaşımın, hastalıkların kent içindeki yapısına ve sağlık hizmetlerine erişebilirlik konularına yönelik üç odak noktası vardır. Bunlardan birincisi, kentsel sağlık sorunları ve bunların nüfus içerisinde dağılımı; ikincisi, hijyenik bir çevre ve etkileri; üçüncüsü ise, hizmetlerin kentsel mekanda nasıl sunulduğudur (Glouberman ve diğerleri, 2006).

İlk odak noktası kentsel sağlık sorunlanı ve nüfus içerisinde dağılımı, kent sakinlerinin sağlığında birçok faktörün rol oynadığını kabul etse de, genel 
olarak belirli sorunlara odaklanır. Bu nedenle kapsam olarak dar olma eğilimindedir ve esas olarak belirli bir alana veya popülasyona yöneliktir (Schroeder, 1998). Örneğin, sağlık sorunları olan topluluklar ve gruplar kısıtlı para ve hizmetlerle rekabet ettikleri için, belirli gruplara yönelik müdahaleler istemeden diğer topluluklara olan ilginin azalmasına neden olabilir (Glouberman ve diğerleri, 2006).

İkinci odak noktası çevresel sorunlardaki çalışmaların çoğu, çevre, konut ve mahallelerin sağlık üzerindeki etkilerine yöneliktir. Örneğin, DSÖ tarafindan birçok ülkede yer alan gecekondulaşma, temiz suya erişim, kanalizasyon altyapısının olmayışı kent sağlığı açısından tehdit unsuru olarak görülmektedir.

Üçüncü odak şehirlerde sağlık hizmetlerinin nasıl sunulduğu konusunda ülkelerdeki yönetimlere büyük görev düşmektedir. Her ne kadar sağlık hizmetleri ülkeler arasında değişkenlik gösterse de ortak özelliği adaletsiz erişimi engellemek ve kentleri sağlık tehditlerine karşı dayanıklı hale getirmektir (Diez ve diğerleri, 2020).

\section{Covid-19 ve Kent Sağlığı}

Yeni Koronavirüs Hastalığ (Covid-19), ilk olarak Çin'in Wuhan Eyaleti'nde 2019 yılı Aralık ayının sonlarında ortaya çıkmış ve Ocak 2020'den itibaren tüm dünyaya yayılmıştır. Salgının küresel boyutta ciddi bir hal almasıyla, 11 Mart 2020'de DSÖ tarafından pandemi ilan edilmiştir.

Kentler, en yüksek nüfus yoğunluğuna sahip yerlerdir ve tarih boyunca bulaşıcı hastalıklara ve salgınlara tanıklık etmiştir. Ebola, SARS, MERS ve şimdi de Covid-19 gibi salgınlar, şehirlere benzersiz zorluklar sunmaktadır. Salgınlar zaman içinde bir anda başlamakta, mekan ve süre bakımından sınırlı bir aşamada ilerlerken, artan etkisi açığa çıktığı zaman bireysel ve kolektif krize doğru ilerleyip kapanmaya doğru sürüklenmektedir (Rosenberg, 1989). Salgin hastalıkların bu seyrinde kentler bulaşıı hastalıkların yayılmasını durdurmak ve nüfus sağlığını iyileştirmek için çözümler sunan yerlerdir (Gatzweiler ve diğerleri, 2020). DSÖ'ye göre Covid-19 pandemisinde kentler üç önemli rol üstlenmiştir. Bunlar; ulusal ve uluslararası merkez, halka en yakın yönetim düzeyi ve ulusal hükümetin operasyonel ortakları rolleridir (World Health Organization Regional Office for Europe, 2020).

Covid-19 salgınında kentler ulusal ve uluslararası merkezler: Kentler, ulusal ve uluslararası seyahat ve ticaret yolları ülke çapında daha fazla aktarıma giriş noktaları olmanın yanı sıra, toplum aktarım merkezleri olarak hare- 
ket ederler (World Health Organization Regional Office for Europe, 2020). Pandeminin ortaya çıkardığı zorlukları ele almak için hızlı ve yenilikçi bir şekilde tepki vermektedir.

Covid-19 salgınında kentler halka en yakın yönetim düzeyi: Pandemi sürecinde güçlü bir halk sağlığ i ç̧in tehditleri anlamak, etkilerini izlemek ve politika rehberliği yapmak gerekmektedir. Pek çok kentte halk sağllğı sürveyans sistemleri yeterince gelişmemiştir. Halk sağlığı kaynakları ve uzmanlığına öncelik verilmemiştir. Bu zorluk özellikle Covid-19 bağlamında belirgin olsa da, şehirlerin tüm sağlık tehditlerine yanıt verme yeteneğini etkileyen çok daha geniş bir zorluktur (Diez ve diğerleri, 2020). Risk iletişimi ve halk sağlığı mesajları ve tavsiyeleri ulusal düzeyde DSÖ'nün rehberliğinde insanlara ulaşarak onları çözümün bir parçası haline getirmeyi hedeflemektedir (World Health Organization Regional Office for Europe, 2020).

Covid-19 salgınında kentler ulusal hükümetin operasyonel ortakları: Kentler, ulusal hazırlık ve müdahale planlarında kilit aktör, temel hizmet sağlayıcısı ve sürdürülebilir bir gelecek oluşturmanın merkezinde yer alırlar (World Health Organization Regional Office for Europe, 2020). Bu noktada pandemi, kentsel politikalar konusunda araştırma yapma ve yeniden düşünme firsatı yaratmış ve kentlerde var olan, yüksek nüfus yoğunluğunun iyi ya da kötü olması gibi yanlış ikilemleri aşarak, politikaların yararlı etkilerinin maksimize edilebileceği koşulları belirleyecek ortam sağlamıştır. Sağlığı iyileştirmek için, kentlerdeki insanlar ve mahalleler arasındaki sosyal ve ekonomik eşitsizlikleri özel olarak ele alan kentsel politikalar ile eşitsizliklerin giderilmesi yönündeki çalışmalara 1şık tutmuştur (Diez ve diğerleri, 2020).

\section{Türkiye'de Sağlık Hizmetlerinin Sunumu ve Covid-19 Önlemleri}

Türkiye'de sağlık hizmetlerinin sunumunda yetkili kurum Sağlık Bakanlığı'dır. Sağlık hizmetlerinin yer seçiminde bakanlıklar, belediyeler ve yatırımclar rol oynamaktadır. Sağlık hizmetlerinin kentsel alandaki nüfusa yetebilirliği ve erişilebilirliği ise Mekânsal Planlar Yapım Yönetmeliği'nde belirtilen standartlara göre belirlenmektedir.

Türkiye Cumhuriyeti Anayasasının 56. Maddesinde sağlık hizmetleri;

- "Herkes, sağlıklı ve dengeli bir çevrede yaşama hakkına sahiptir.

- Devlet, herkesin hayatını, beden ve ruh sağllğı içinde sürdürmesini sağlamak; insan ve madde gücünde tasarruf ve verimi artırarak, işbirliğini gerçekleştirmek amacıyla sağlık kuruluşlarını tek elden planlayıp hizmet vermesini düzenler. 
- Devlet, bu görevini kamu ve özel kesimlerdeki sağlık ve sosyal kurumlarından yararlanarak onları denetleyerek yerine getirir.

- Sağlık hizmetlerinin yaygın bir şekilde yerine getirilmesi için kanunla genel sağlik sigortası kurulabilir."

şeklinde tanımlanmıştır.

Cumhurbaşkanlığı Teşkilatı Hakkında Cumhurbaşkanlığı Kararnamesi'nde herkesin bedenî, zihnî ve sosyal bakımdan tam bir iyilik hâli içinde hayatını sürdürmesini sağlamak amacıyla, Sağlık Bakanlığı'nın görev ve yetkileri;

- "Halk sağlığının korunması ve geliştirilmesi, hastalık risklerinin azaltılması ve önlenmesi için çalışmalar yapmak,

- Teşhis, tedavi ve rehabilite edici sağlık hizmetlerinin yürütmek,

- Uluslararası önemi haiz halk sağllğı risklerinin ülkeye girmesini önlemek,

- Sağlık eğitimi ve araştırma faaliyetlerini geliştirmek,

- Sağlık hizmetlerinde kullanılan ilaçlar, özel ürünler, ulusal ve uluslararası kontrole tâbi maddeler, ilaçüretiminde kullanılan etken ve yardımcı maddeler, kozmetikler ve tıbbî cihazların güvenli ve kaliteli bir şekilde piyasaya sunulması, halka ulaştırılması ve fiyatlarının belirlenmesi için çalışmalar yapmak,

- İnsan gücünde ve maddî kaynaklarda tasarruf sağlamak ve verimi artırmak, sağlık insan gücünün ülke sathında dengeli dağllımını sağlamak ve bütün paydaşlar arasında işbirliğini gerçekleştirmek suretiyle yurt sathında eşit, kaliteli ve verimli hizmet sunumunu sağlamak,

- Kamu ve özel hukuk tüzel kişileri ile gerçek kişiler tarafından açılacak sağlık kuruluşlarının

- Ülke sathında planlanması ve yaygınlaştııılması için çalışmalar yapmak,

- Kanunlarla ve Cumhurbaşkanlığı kararnameleri ile verilen diğer görevleri yapmak"

olarak belirlenmiştir.

Türkiye'de sağlık hizmetlerinin sunumunda 2019 yılında Sağlık Bakanlığı Sağlık Hizmetleri Genel Müdürlügü tarafından yayınlanan genelgede sağlık hizmetleri; koruyucu, tedavi edici ve rehabilite edici hizmetler olmak üzere üç ana başlıkta sınıflandırılmış ve sağlık hizmeti sunucuları basamaklandırılmıştır (Tablo 1). Bu genelge kapsamında;

- Birinci basamak sağlık hizmetleri ilgili mevzuatta tanımlanan, hastaların ayaktan veya yataklı teşhis ve tedavilerinin yapıldığı sağlık kuruluşları,

- İkinci basamak sağlık kurumları, ilgili mevzuatta tanımlanan ayaktan veya yataklı teşhis, tedavi ve rehabilitasyon hizmeti verilen sağlık kurumları, 
- Üçüncü basamak sağlık kurumları, ileri tetkik ve özel tedavi gerektiren hastalıklar için yüksek teknoloji içeren veya gerekli altyapıya sahip eğitim ve araştırma hizmetlerinin verildiği sağlık kurumlarını kapsamaktadır.

Tablo 1. Sağlık hizmeti sunucularının basamaklandırılması (Kaynak: 2019 yılı Sağlık Bakanlığı Sağlık Hizmetleri Genel Müdürlüğü tarafından yayınlanan genelge verileri kullanılarak yazarlar tarafından oluşturulmuştur.)

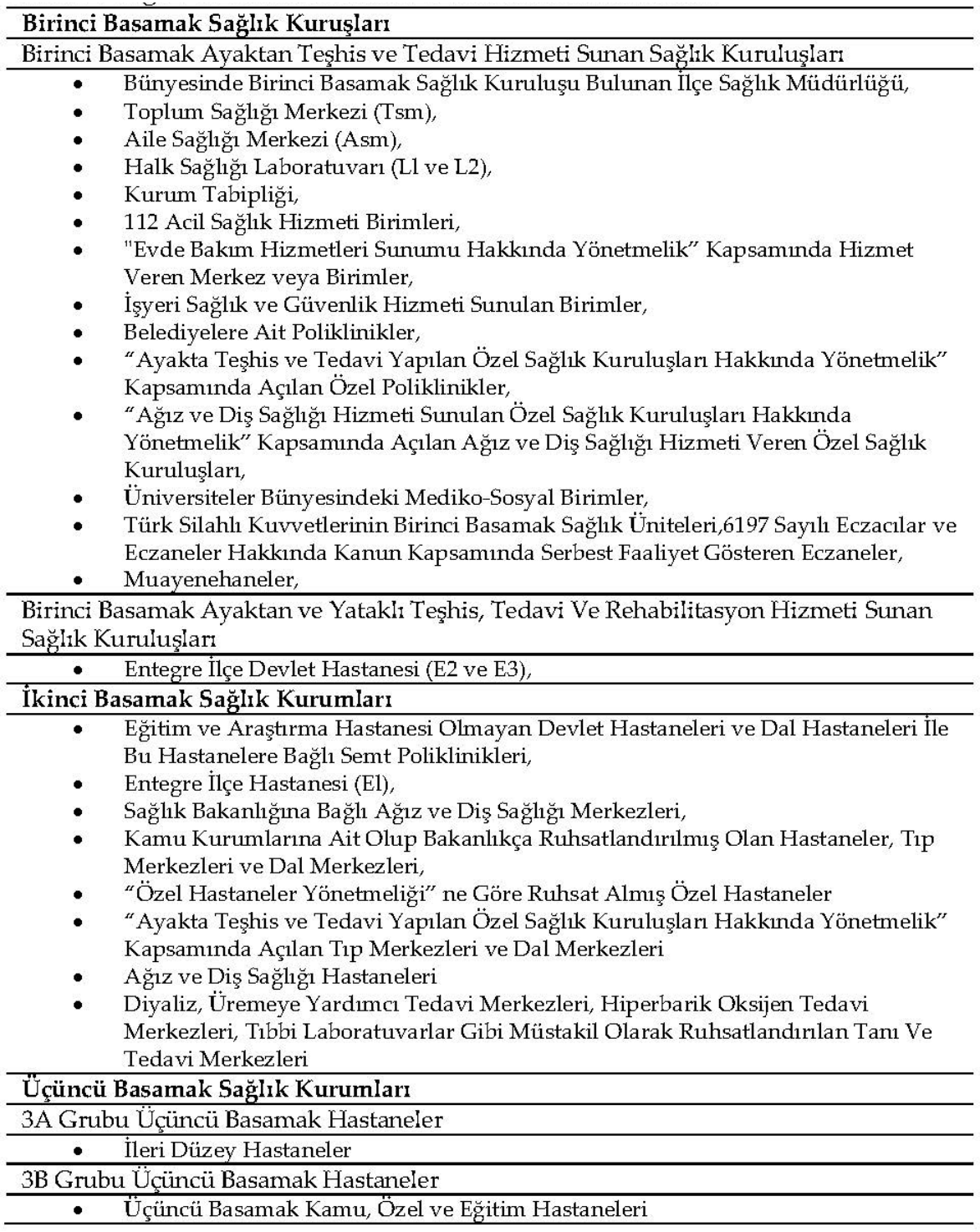


Türkiye'de yer alan kamu-özel ortaklığı ile inşa edilen ve faaliyet gösteren entegre sağlık kampüsleri diğer bir deyişle şehir hastaneleri bu sınıflandırma içinde yer almamaktadır.

Türkiye'de ülke, bölge ve şehir düzeyinde sürdürülebilir kalkınmayı desteklemek, yaşam kalitesi yüksek, sağlıklı ve güvenli çevreler oluşturmak üzere hazırlanan, arazi kullanım ve yapılaşma kararları getiren mekânsal planların yapımına ve uygulanmasına ilişkin usul ve esasları belirleyen Mekansal Planlar Yapım Yönetmeliği 14 Haziran 2014 tarih 29030 sayılı Resmi Gazetede yayınlanarak yürürlüğe girmiştir. Türkiye'de gerek özel sektör tarafından gerekse kamu kurum ve kuruluşları tarafından yapılan her tür ve ölçekteki mekânsal planlara ilişkin revizyon, ilave ve değişikliklerin yapılması incelenmesi usul ve esaslar bakımından bu yönetmelik kapsamındadır.

Yönetmeliğin eki olan farklı nüfus gruplarında asgari sosyal ve teknik altyapı alanlarına ilişkin standartlar ve asgari alan büyüklükleri tablosu Türkiye'de yapılan imar planlarında dört farklı nüfus grup aralığını esas alarak sosyal ve teknik altyapı alanlarına ilişkin kişi başı metrekare ve asgari alan büyüklüklerini belirleyen yasal dayanaktır. Her tür ve ölçekteki mekânsal planlardaki sağlık tesisi alanları sekiz gruba ayrılmakta olup sağlık tesis alanının niteliğine ve ihtiyacına göre asgari birim alanlar belirlenmiştir. Asgari birim alanların yanı sıra kişi başı metrekare büyüklüğü de nüfus gruplarına göre değişiklik göstermektedir (Tablo 2). 
Tablo 2: Farklı nüfus gruplarında asgari sosyal ve teknik altyapı alanlarına ilişkin standartlar ve asgari alan büyüklüklere göre sağlık tesis alanları kriterleri (Kaynak: Mekansal Planlar Yapım Yönetmeliği EK-2 tablosu verileri kullanılarak yazarlar tarafından oluşturulmuştur.)

\begin{tabular}{|c|c|c|c|c|c|c|c|c|}
\hline Nüfus Grupları & \multicolumn{2}{|c|}{$0-75.000$} & \multicolumn{2}{|c|}{$\begin{array}{l}75.001- \\
150.000 \\
\end{array}$} & \multicolumn{2}{|c|}{$\begin{array}{c}150.001 \text { - } \\
500.000 \\
\end{array}$} & \multicolumn{2}{|r|}{$501.000+$} \\
\hline $\begin{array}{l}\text { Altyapı } \\
\text { Alanları }\end{array}$ & $\underset{\substack{n \\
n}}{\stackrel{n}{n}}$ & 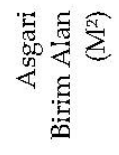 & $\frac{\sin _{n}}{\sum_{i}^{2}}$ & 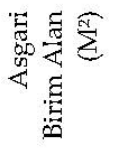 & 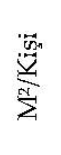 & 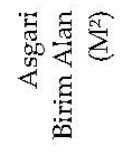 & $\frac{w_{n=n}^{n}}{\sum_{n}^{n}}$ & 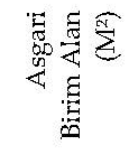 \\
\hline $\begin{array}{l}\text { Aile Sağltk } \\
\text { Merkezi }\end{array}$ & & $\begin{array}{r}750- \\
2.000 \\
\end{array}$ & & $\begin{array}{r}750- \\
2.000 \\
\end{array}$ & & $750-2.000$ & & $\begin{array}{r}750- \\
2.000 \\
\end{array}$ \\
\hline $\begin{array}{l}\text { Basamak Sağlık } \\
\text { Tesisleri }\end{array}$ & & 3.000 & & 3.000 & & 3.000 & & 3.000 \\
\hline $\begin{array}{l}\text { Ağız ve Diş } \\
\text { Sağlığı Merkezi }\end{array}$ & & $\begin{array}{r}\text { Ùnit } \\
\text { Başına } \\
(110) M^{2} \\
\end{array}$ & & $\begin{array}{r}\text { Ünit } \\
\text { Başına } \\
(110) \mathrm{M}^{2} \\
\end{array}$ & & $\begin{array}{r}\text { Ünit } \\
\text { Başına } \\
(110) M^{2} \\
\end{array}$ & & $\begin{array}{r}\text { Ünit } \\
\text { Başına } \\
(110) M^{2} \\
\end{array}$ \\
\hline $\begin{array}{l}\text {-Doğum ve } \\
\text { Çocuk Bakım } \\
\text { Evleri } \\
\text { •Devlet } \\
\text { Hastaneleri } \\
\text { İhtisas/Eğitim } \\
\text { ve Araştrma } \\
\text { Hastaneleri } \\
\text {-Fizik Tedavi ve } \\
\text { Rehabilitasyon } \\
\text { Hastaneleri } \\
\end{array}$ & $\stackrel{\text { 菅 }}{\rightarrow}$ & $\begin{array}{r}\text { Yatak } \\
\text { Başina } \\
\text { (130) } M^{2}\end{array}$ & $\stackrel{\text { 号 }}{\rightarrow}$ & $\begin{array}{r}\text { Yatak } \\
\text { Başına } \\
\text { (130) } M^{2}\end{array}$ & 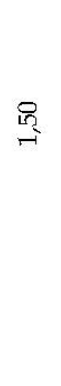 & $\begin{array}{r}\text { Yatak } \\
\text { Başina } \\
(130) M^{2}\end{array}$ & $\stackrel{8}{-}$ & $\begin{array}{r}\text { Yatak } \\
\text { Başına } \\
(130) M^{2}\end{array}$ \\
\hline $\begin{array}{l}\text { Sağltk } \\
\text { Kampüsleri }\end{array}$ & & $\begin{array}{r}\text { Yatak } \\
\text { Başına } \\
(220) M^{2}\end{array}$ & & $\begin{array}{r}\text { Yatak } \\
\text { Başına } \\
(220) \mathrm{M}^{2}\end{array}$ & & $\begin{array}{r}\text { Yatak } \\
\text { Başina } \\
(220) \mathrm{M}^{2}\end{array}$ & & $\begin{array}{r}\text { Yatak } \\
\text { Başına } \\
(220) M^{2}\end{array}$ \\
\hline
\end{tabular}

Açıklamalar:

1. Standartlara ilişkin alan hesabında; öncelikle varsa üst kademe mekansal planlarda belirlenen ilçe projeksiyon nüfusunun yer aldığı veya kent bütününe yönelik nazım imar planında belirlenen ilçe projeksiyon nüfusunun bulunduğu nüfus grubundaki standartlara uyulur.

2. Büyükşehir belediye smırları içerisinde yerleşme bütünlüğü gösteren, komşu ilçe belediyeleri ile bütünleşen ilçe belediyelerinde altyapı alanlan bir bütün olarak hesaplanabilir.

6. Aile sağlık merkezi 1. basamak sağlık tesisi olarak değerlendirilecektir.

7. Toplum sağhı̆̆ı merkezi, acil sağlık merkezi,112 acil sağlık merkezi ve istasyonlan basamak sağltk tesisleri içinde yer alır.

8. İmar planlarmda ayrılmış bulunan ve kamu niteliğgi taşıyan kreş + anaokulu, ilköğretim, ortaöğretim, sağlık tesisi, kültürel tesis, sosyal tesis alanlan; imar planı değişikliğ i yapılmak suretiyle bu kullanımlarm başına "özel" ibaresi getirilmek, kamu ve özel altyapı oranları ilgili yatırımc bakanlık veya kamu kuruluşunca belirlenmek kaydıyla, bu tabloda belirtilen kişi başına asgari standart değerinin içinde yer alır. 
Mekansal planlamada sosyal ve teknik altyapı alanlarına ilişkin standartlar ve asgari alan büyüklüklerin yanı sıra sunulan bu hizmetlere erişimde büyük önem taşımaktadır. Mekânsal Planlar Yapım Yönetmeliği'nde yürüme mesafesi, "imar planlarında eğitim, sağlık ile yeşil alanların hizmet etki alanındaki nüfusun erişme mesafesi topoğrafya, yapılaşma, yoğunluk, mevcut doku, doğal ve yapay eşikler dikkate alınarak planlanır." şeklinde tanımlanmıştır. Sağlık tesisleri için yürüme mesafesi sadece aile sağllğı merkezleri için belirlenmiş olup 500 metredir.

Covid-19'un ilk olarak ortaya çıkması ve Çin'de yayılma başlamasıyla beraber Türkiye'de hastalığın yayılmasını önlemek ve tedavi etmek için çeşitli önlemler alınmış ve alınmaya devam etmektedir. Türkiye'de Sağlık Bakanlığı'nın koordinatörlüğünde ulusal ve uluslararası kurum ve kuruluşları ile beraber ortaklaşa çalışmalar gerçekleştirilmiştir. Bu çalışmalar kapsamında salgının ortaya çıkması ile beraber ülke genelinde hastalığın yayılmasını önlemek amacryla (Anadolu Ajansı Covid-19 haber geçmişi, 2021);

- Vaka tespit edilen ülkeler ile yapılan uçuşlar ve sınır kapıları kapatılmıştir.

- Salgının başlarında öğrenci yurtları organize edilerek, yurtdışından gelen tüm ziyaretçiler ve vatandaşlar bu yurtlarda karantina altında tutulmuştur.

- Eğitime ara verilerek uzaktan eğitime geçilmiştir. Ancak salgının seyrine göre bir dönem ilk ve orta dereceli okullarda yüz yüze eğitime başlansa da artan vaka sayılarından sonra tekrar uzaktan eğitime geçilmiştir.

- Salgınin ilk başlarında toplu faaliyetlerin yoğun olduğu eğlence mekânları, kafeler, restoranlar, camiler, spor müsabakaları ve kültürel etkinliklere yönelik faaliyet gösteren sektörel faaliyetlerde hizmete ara verilmiştir. Yaklaşık bir yıllık süreç içerisinde vaka sayılarının artış ve azalışına göre kademeli olarak koşullarda esneklikler sağlanmıştır.

- Salgının Türkiye'de başlamasından bir ay sonra 30 büyükşehir ve Zonguldak ili de dâhil toplam 31 şehirde kente giriş ve çıkışlar yaklaşık bir ay süre ile yasaklanmış, ülke genelinde iç hat ve diş hat uçuş seferlerine kısıtlamalar getirilmiştir.

- 20 yaş altı ve 65 yaş üstündeki vatandaşlara sokağa çıkma kısıtlaması getirilmiştir.

- Dönemsel olarak tedarik ve üretim zincirleri aksamayacak şekilde sokağa çıkma kısıtlamaları getirilmiştir.

Sağlık Bakanlı̆̆ı'nca sağlık hizmetlerinin yönetimi ve işlemesine yönelik alınan kararlar ise (Anadolu Ajansı Covid-19 haber geçmişi, 2021); 
- 10 Ocak 2020 tarihinde Sağlık Bakanlığı'nın koordinatörlüğünde, Koronavirüs Bilim Kurulu ve Operasyon Merkezi kurulmuştur.

- Sağlık Bakanlığı'nca belirlenen kriterleri taşıyan tüm hastaneler pandemi hastanesi ilan edilmiştir.

- Filyasyon ${ }^{7}$ ekipleri oluşturularak hasta ve temaslı taramasına başlanılmiştır.

- Ülke genelinde maske takma zorunluluğu getirilmiştir.

- Hastalık ile ilgili bilgi alabilmesi için Korona Danışma Hattı, süreci takip edebilmek için ise Hayat Eve Sığar uygulaması oluşturulmuştur.

- Hastalığın tespitine yönelik olarak yapılan testlerin hızlı sonuçlanması ve test sayısını artırmak amacıyla ülke genelinde laboratuvarlarda düzenleme ve koordinasyon sağlanmıştır.

- İstanbul'da iki adet pandemi hastanesi inşa edilmiş ve hizmet vermeye başlamıştır.

- Artan yoğun bakım cihazı talebini karşılamak amacıyla yoğun bakım cihazları üretimi yapılmış ve hastanelerde kullanımları sağlanmıştır.

- Çeşitli algoritmalar geliştirerek bu algoritmalar çerçevesinde tanı, teşhis ve tedavi yöntemleri geliştirmiştir.

- Türkiye'de hizmet veren Birinci, İkinci ve Üçüncü Basamak Sağlık Hizmetlerinin bu süreçteki organizasyonu yeniden tanımlanmıştır.

\section{Ankara Çankaya İlçesi Örneği}

Pandemi sürecinde izlenen politikalar kapsamında Koronavirüs Bilim Kurulu toplantılarından sonra Sağlık Bakanlığı yetkilileri tarafından yapılan açıklamalar ve paylaşımlarda Ağustos ayında hasta sayısı bakımından artış eğilimi yaşayan Ankara, Eylül ayının ilk haftasında Türkiye'de en fazla vaka sayısına sahip il olmuştur. Pandemi sürecinde Covid-19'a yönelik veriler Sağlık Bakanlığı tarafından geliştirilen Hayat Eve Sığar uygulaması ve Sağlık Bakanlığı'nın Covid-19 web sitesinden yayınlanmıştır. Covid-19 web sitesinden yayınlanan veriler Türkiye İstatistiki Bölge Birimleri Sınıflandırması (IBBBS) Düzey-1 bölgeleri ile açıklanırken, Hayat Eve Sığar uygulamasındaki veriler ise Covid-19 testi pozitif olan kişilerin yoğun olarak bulundukları bölgeleri gösterir yoğunluk haritası ile gösterilmiştir. Covid-19 vaka sayılarına yönelik veri temini sürecinde, yetkililerle yapılan şifahi görüşmelerde "yapılan testlerin sağlık kuruluşların-

\footnotetext{
${ }^{7}$ Bulaşıcı bir hastalık varlığında, hastalığı taşıyan kişinin temas ettiği herkesin o hastalık açısından taranması (T.C. Covid-19 bilgilendirme platformu Covid-19 sözlüğü, 2021).
} 
dan toplanması ve sağlık kuruluşlarının mekânsal farklılık göstermesinden dolayı ilçelere göre dağılımın gerçekçi olmayacağı" belirtilmiştir. Yaşanan bu süreçte Ankara İlinde Çankaya ilçesi;

- Ankara'nın merkez ilçesi olması ve nüfus bakımından en kalabalık ilçesi olmasi,

- Kamu kurum ve kuruluşları ile birlikte önemli ticaret alanlarının ve toplu taşım güzergâhlarının ilçede yer almasıyla beraber hareketliliğin ve bu hareketlilik ile beraber bulaş riskinin fazla olduğu ilçe konumunda olması,

- Ankara'nun çeşitli ilçelerinde yer alan hastanelerin resmi açlışı 14 Mart 2019 tarihinde gerçekleşen Ankara Şehir Hastanesi'ne taşınması ve pandemi hastanesi olarak kabul edilen bu şehir hastanesinin ilçede yer seçmesi,

nedenleriyle detayda analiz edilecek örnek çalışma alanı olarak belirlenmiştir.

Ankara Illi sınırları içerisinde yer alan ve 2019 yılı Türkiye İstatistik Kurumu Adrese Dayalı Nüfus Kayıt Sistemi (ADNKS) verilerine göre en fazla nüfusa (944 609 kişi) sahip merkez ilçelerden biri olan Çankaya İçesi 124 mahalleden oluşmaktadır (Şekil 1). Kamu kurum ve kuruluşlarının, eğitim ve sağlık tesisi alanlarının yanı sıra önemli ticaret, sosyal ve kültürel merkezlerin yer aldığı en önemli ilçe konumundadır.

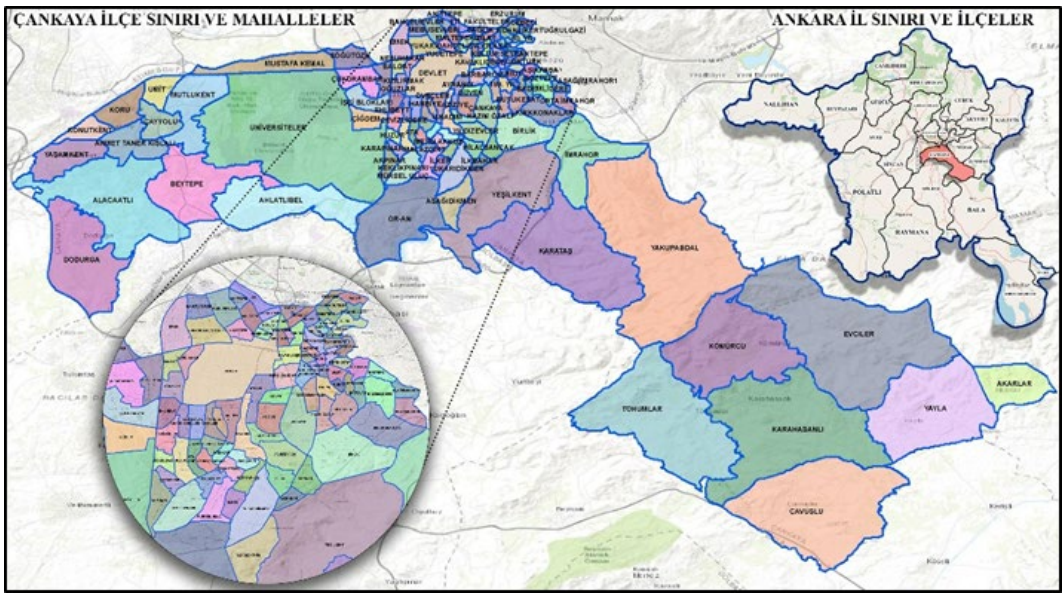

Şekil 1. Çankaya ilçesi ve mahalleleri

(Çankaya Belediyesi verileri kullanılarak yazarlar tarafindan oluşturulmuştur.)

Çalışma alanı olarak belirlenen Çankaya ilçesi sınırları içerisinde sağlık hizmetlerinin sunumunu ölçmek için iki aşamalı bir yöntem izlenmiştir. İlk aşamada; sağlık hizmet alanlarının mekânsal yer seçimi kararlarına yönelik veriler 
Sağlık Bakanlığı, Çankaya Kaymakamlığı ve Çankaya Belediyesi İmar ve Şehircilik Müdürlüğü'nden temin edilmiştir. İkinci aşamada ise; Covid-19 sürecinde aktif hizmet veren sağlık kurum ve kuruluşları, 2019 yılında Sağlık Bakanlığı Sağlık Hizmetleri Genel Müdürlügü tarafindan yayınlanan genelgede belirlenen sisteme göre sınıflandırılmıştır. Farklı kademedeki sağlık hizmetlerinin kanunlar kapsamında belirlenen standartlara uygunluğu ve bölgenin demografik özelliklerine göre erişilebilirliği coğrafi bilgi sistemleri aracılığıyla analiz edilmiştir. Çalışmaya Sağlık Bakanlığı tarafından ruhsatlandırılarak halkın kullanımına sunulmuş sağlık tesisi dışındaki özel sağlık tesisleri dahil edilmemiştir.

\section{Birinci Basamak Sağlık Kuruluşları}

2019 yılında Sağlık Bakanlığı Sağlık Hizmetleri Genel Müdürlüğü tarafından yayınlanan genelgede birinci basamak sağlık kuruşları; hastaların ayakta veya yataklı teşhis ve tedavilerin yapıldığı kuruluşlardır. Çankaya ilçesi sınırları içerisinde Covid-19 salgınına karşı birinci basamak sağlık hizmeti sunan toplam 59 adet aile sağllğı merkezinin aktif faaliyet gösterdiği görülmektedir.

Çankaya ilçesinde yer alan aile sağlığı merkezlerinin konumları tespit edilirken Çankaya Kaymakamlığı ve Sağlık Bakanlığı verilerinden yararlanılmıştır. Adrese dayalı olarak yapılan analizler sonucu aile sağlığı merkezlerinin \%71,19'luk kesiminin konut alanı kullanımı içerisinde yer aldığı saptanmıştır. Konut alanları içerisinde yer alan aile sağlığı merkezlerinin büyüklüklerinin Mekânsal Planlar Yapım Yönetmeliği'nde belirlenen 750-2000 asgari birim m² 'yi sağlamadığı ve konutlarla iç içe yer aldığı tespit edilmiştir. Adrese dayalı elde edilen veriler yürürlükteki imar planı ile karşılaştırıldığında sadece $\% 6,78^{\prime}$ lik kesiminin sağlık tesisi alanı olduğu ve standartları sağladığı saptanmiştır (Tablo 3).

Tablo 3: Ankara Çankaya ilçesi aile sağlığı merkezleri imar durumu (Kaynak: Çankaya Bele$\underline{\text { diyesi ve Çankaya Kaymakamlığı verileri kullanılarak yazarlar tarafından oluşturulmuştur.) }}$

\begin{tabular}{lrr}
\hline İmar Durumu & Adet & Yüzde \\
\hline Konut Alanı & 42 & 71,19 \\
Merkezi İş Alanı & 2 & 3,39 \\
Ticaret Yolu & 1 & 1,69 \\
Sağlık Tesisi Alanı & 4 & 6,78 \\
Anaokulu & 1 & 1,69 \\
Belediye Hizmet Alanı & 3 & 5,08 \\
Pazar Alanı & 2 & 3,39 \\
Sosyal ve Kültürel Tesis Alanı & 1 & 1,69 \\
Fonksiyonsuz Alan & 1 & 1,69 \\
Bilinmeyen & 2 & 3,39 \\
\hline Toplam & $\mathbf{5 9}$ & $\mathbf{1 0 0}$ \\
\hline
\end{tabular}


Bireylerin ve aile fertlerinin ikamet yerlerinin yakınlarında ya da kolaylıkla ulaşabilecekleri bir yerde bulunan (T.C Sağlık Bakanlığı Halk Sağlığı Genel Müdürlüğü, 2020) aile sağlığı merkezlerine; ilaç yazdırma, muayene, enjeksiyon, pansuman gibi tıbbi işlemlerin yanı sıra koruyucu sağlık hizmetleri ve çeşitli sağlık raporları için başvurulmaktadır. Pandemi sürecinde Sağlık Bakanlığı tarafından, ikinci ve üçüncü basamak sağlık sunucularında oluşabilecek yoğunluğu azaltmak için hastalar ilk olarak aile sağlığı merkezlerine yönlendirilmiştir (Samanc, 2020). Aile sağlığı merkezlerinde Covid-19 şüphelisi olduğuna kanaat getirilen kişiler izolasyon kurallarına uyularak ikinci ve üçüncü basamak sağlık birimlerine sevk edilmiştir. Ayrıca konu ile ilgili bilgiler il ve ilçe sağllk müdürlüklerine de iletilmiştir. Covid-19'lu hasta ile herhangi bir temas olduğunda ve/veya kişilerde herhangi bir bulgu görüldüğünde aile hekimleri ile irtibata geçilmiş ve evde izolasyona tabii olan hastaların kontrol ve takipleri de aile hekimleri tarafından yapılmıştır (Yücesan ve Özkan, 2020).

Erişilebilirliğin önem kazandığı bu dönemde aile sağlığı merkezlerine gerekli durumlarda hızla erişebilmek de önemlidir. Sağlık Bakanlığı tarafından aile hekimliği seçim kriteri olarak "bölge sınırlaması olmaksızın kişilerin aile hekimliği hizmetlerine hızlı ve kolay erişimi için ikamet edilen konuma en yakın aile hekimliğine kayıt olması gerektiği" belirtilmektedir. Mekânsal Planlar Yapım Yönetmeliği'nde ise sağlık tesisi alanları için belirtilen erişim, yürüme mesafesi olarak tanımlanmakta ve bu mesafe 500 metre olarak belirtilmektedir. Yapılan çalışmada hem Sağlık Bakanlığı, hem de Mekânsal Planlar Yapım Yönetmeliği'nde belirtilen kriterler dikkate alınarak kuş uçuşu yürüme mesafesi hesaplanmıştır. Böylece her bir aile sağlığı merkezinin etki alanı belirlenmiştir.

Ankara Çankaya ilçesinde yer alan aile sağlı̆̆ı merkezlerinin erişilebilirliği incelendiğinde; kentin doğusundaki konut yerleşim alanlarında aile sağlı̆̆ı merkezlerinin görece daha erişilebilir olduğu, batısında ve özellikle yeni gelişen bölgelerde ise aile sağlığı merkezlerinin erişilebilirlik mesafelerinin arttı̆̆ ve görece daha az erişilebilir oldukları görülmektedir (Şekil 2). 


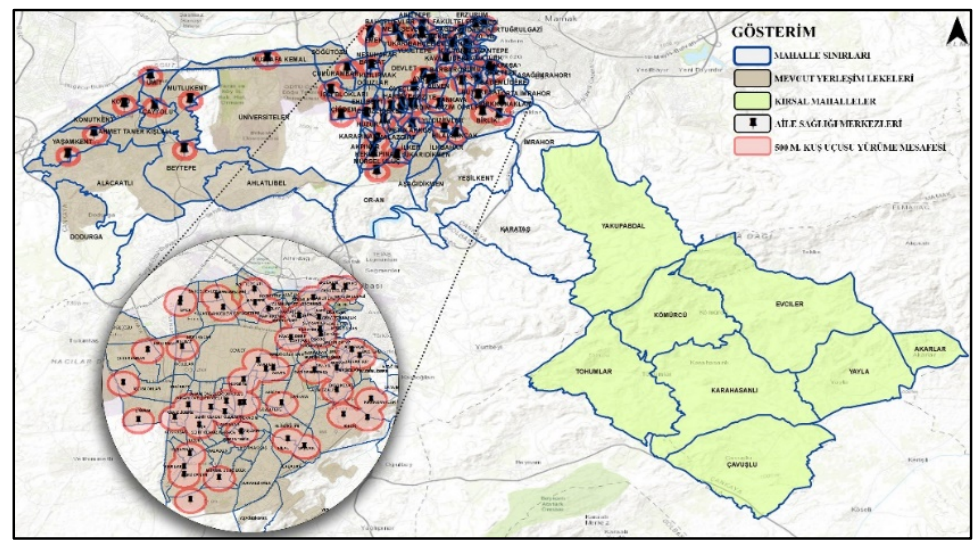

Şekil 2. Çankaya ilçesi aile sağlığı merkezleri dağılımı ve yürüme mesafeleri

(Sağlık Bakanlığı ve Çankaya Belediyesi verileri kullanılarak yazarlar tarafından oluşturulmuştur.)

\section{İkinci Basamak Sağlik Kuruluşlarn}

2019 yılında Sağlık Bakanlığı Sağlık Hizmetleri Genel Müdürlüğü tarafından yayınlanan genelgede ikinci basamak sağlık kurumları, ayakta veya yataklı teşhis ve rehabilitasyon hizmetlerinin yapıldığı kurumlar olarak tanımlanmıştır. Türkiye'de Covid-19 vakaları görülmeye başladığından beri hastalara yönelik sağlık hizmetleri ikinci ve üçüncü basamak sağlık kurumları olan hastaneler tarafından karşılanmaktadır. Salgının Türkiye'de görülmesiyle beraber Sağlık Bakanlığı tarafından belirli hastaneler pandemi hastanesi ilan edilmiştir. Salgının yayılmasına bağlı olarak hasta sayısının hızla artmasıyla birlikte, bünyesinde enfeksiyon hastalıkları ve klinik mikrobiyoloji, göğüs hastalıkları, iç hastalıkları branşlarından en az ikisinin bulunduğu ve üçüncü seviye erişkin yoğun bakım yatağı bulunan Sağlık Bakanlığı'na bağlı hastaneler, devlet ve vakıf üniversitesi hastaneleri ile tüm özel sağlık kuruluşları pandemi hastanesi ${ }^{8}$ olmuştur (Öztürk ve Karcıoğlu, 2020). Pandemi hastaneleri ile birlikte sağlık sisteminin tüm kaynaklarıyla pandemiye karşı hazırlıklı olması amaçlanmıştır. Çankaya ilçesi sınırları içerisinde pandemi hastanesi olarak hizmet veren tek sağlık kuruluşu Ankara Şehir Hastanesi'dir (Anadolu Ajansı Covid-19 haber geçmişi, 2021).

İl-ilçe bütünü ve mahalle bazlı yapılan imar planlarında sağlık tesisi alanları belirlenirken, ihtiyacın yanı sıra, plan bütününde Mekânsal Planlar Yapım Yö-

\footnotetext{
${ }^{8}$ Pandemiye neden olan hastalığı taşıyanların tedavisi için özel olarak görevlendirilmiş ve organize edilmiş yataklı sağlık kuruluşu (T.C. Covid-19 bilgilendirme platformu Covid-19 sözlüğü, 2021).
} 
netmeliği'nde yer alan standartları sağlamaya ve erişilebilirliğe yönelik yer seçimi yapılmaktadır. Ancak erişebilirlik kriteri olarak, ikinci ve üçüncü basamak sağlık hizmetlerine yönelik Yönetmelikte herhangi bir kriter bulunmamaktadır. Mekânsal uygulamaya yönelik koşulların yer aldığı Mekânsal Planlar Yapım Yönetmeliği ile Sağlık Bakanlığı tarafından belirlenen sağlık kuruluşlarına yönelik basamak sınıflandırmasının birbiriyle örtüşmemesi, sağllk tesisi alanlarını sinıflandırılmasında ve planlanmasında tutarsızlıklar yaratmaktadır. Benzer şekilde Mekansal Planlar Yapım Yönetmeliği'ne ek olarak imar planlarının yapımında ve uygulamasında 03.07.2017 tarih 30113 sayılı Resmî Gazete yayımlanarak yürürlüğe giren Planlı Alanlar İmar Yönetmeliği'ne göre de sağlik alanlarının; merkezi iş alanı ${ }^{9}$, resmi kurum alanı ${ }^{10}$ ve belediye hizmet alanı ${ }^{11}$ gibi alanlar içerisinde de yer alabileceği açıklaması, pandemi döneminde sağlık alanlarının diğer kullanımlardan ayrı, izole edilmesi gereken özel alanlar olması yaklaşımı ile çelişmektedir.

Çankaya ilçesinde yer alan ikinci basamak sağlık kuruluşlarının mekansal konumlarının belirlenmesinde Çankaya Belediyesi İmar ve Şehircilik Müdürlüğü'nden temin edilen yürürlükteki imar planı ve mevcut arazi kullanımı verilerinden yararlanılmıştır (Şekil 3).

\footnotetext{
${ }^{9}$ Yönetimle ilgili idari tesis alanları, iş hanı, çarşı, çok katlı mağaza, banka gibi ticaret ve finans tesis alanları, turizm tesis alanları, sosyal kültürel tesis alanları, ibadet yerleri, park ve benzeri yeşil alanlar, spor alanları kamuya ve özel sektöre ait eğitim ve sağlık tesisleri alanları, kamuya ve özel sektöre ait teknik altyapı tesis alanları ile bu alanlara hizmet verecek benzeri alanlar ve plan kararı ile rezidans alanı ayrilır.

${ }^{10}$ Genel bütçe kapsamındaki kamu idareleri ile özel bütçeli idarelerle, il özel idaresi ve belediyeye veya bu kurumlarca sermayesinin yarısından fazlası karşılanan kuruluşlara, kanunla veya kanunun verdiği yetki ile kurulmuş kamu tüzel kişilerine ait bina ve tesislerin yapıldığı alanlardır ${ }^{11}$ Belediyelerin görev ve sorumlulukları kapsamındaki hizmetlerinin götürülebilmesi için gerekli itfaiye, acil yardım ve kurtarma, ulaşıma yönelik transfer istasyonu, araç ve makine parkı, bakım ve ikmal istasyonu, garaj ve triyaj alanları, belediye depoları, asfalt tesisi, atık işleme tesisi, zabıta birimleri, mezbaha, ekmek üretim tesisi, pazar yeri, idari, sosyal ve kültürel merkez gibi mahallî müşterek nitelikteki ihtiyaçları karşılamak üzere kurulan tesisler ile sermayesinin yarıdan fazlası belediyeye ait olan şirketlerin sahip olduğu tesislerin yapılabileceği alandır.
} 


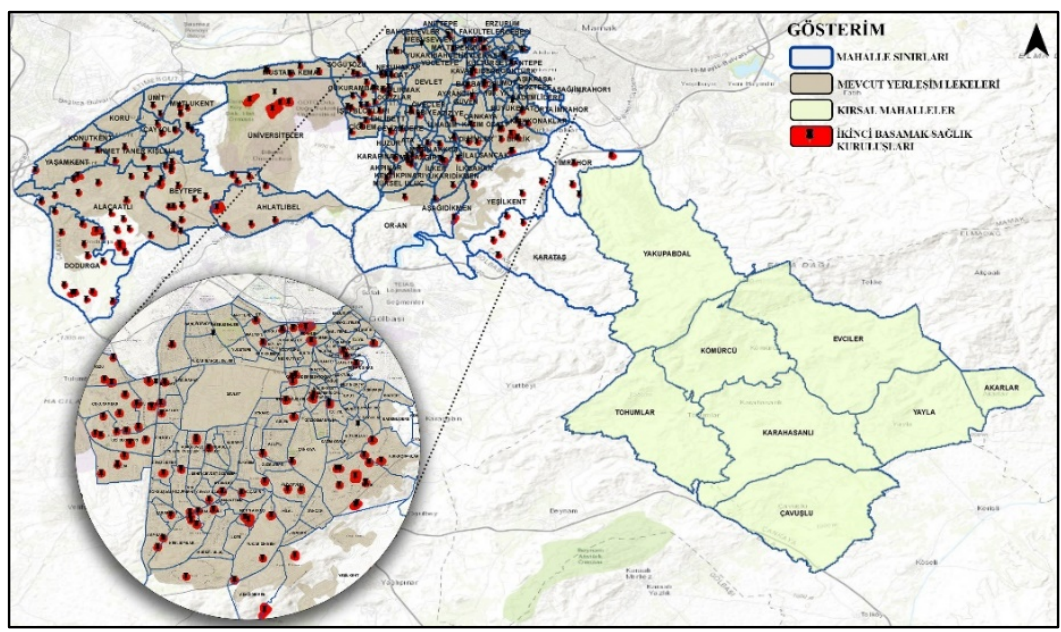

Şekil 3. Çankaya ilçesi ikinci basamak sağlık kuruluşları

(Çankaya Belediyesi verileri kullanılarak yazarlar tarafindan oluşturulmuştur.)

Mekânsal Planlar Yapım Yönetmeliği'nin Ek-2 tablosu olan farklı nüfus gruplarında asgari sosyal ve teknik altyapı alanlarına ilişkin standart hesabı yapıldığında, Çankaya ilçe bütününde yürürlükteki imar planında yer alan sağlık tesisi alanlarının kişi başına 1,47 m² olduğu görülmektedir (Tablo 4). Çankaya ilçesi bütününde yapılan bu analiz sonucunda yürürlükteki imar planlarında yer alan ikinci basamak sağlık tesisi alanlarının Yönetmelikte belirtilen asgari sosyal ve teknik altyapı standartlarının altında kaldığı gözlemlenmiştir.

Tablo 4. Ankara Çankaya ilçesi ikinci basamak sağlık kuruluşlarına ilişkin standartlar (Kaynak: Çankaya Belediyesi ve Türkiye İstatistik Kurumu (TÜIK) Adrese Dayalı Nüfus Kayıt Sistemi (ADNKS) verileri kullanılarak yazarlar tarafından oluşturulmuştur.)

\begin{tabular}{llll}
\hline $\begin{array}{l}\mathbf{2 0 1 9} \text { Yılı } \\
\text { Çankaya İlçesi } \\
\text { Nüfusu }\end{array}$ & $\begin{array}{l}\text { Çankaya İlçesi İkinci } \\
\text { Basamak Sağlık } \\
\left.\text { Alanları } \mathbf{~ M}^{2}\right)\end{array}$ & $\begin{array}{l}\text { Çankaya İlçesi } \\
\text { Sağlık Alanları } \\
\mathbf{( M}^{2} / \text { Kişi) }\end{array}$ & $\begin{array}{l}\text { Standart } \\
\text { (M2/Kişi) }\end{array}$ \\
\hline 944609 & 1396669,11 & 1.47 & 1.60 \\
\hline
\end{tabular}

Çankaya ilçesinde sosyal ve teknik altyapı alanlarına ilişkin mahalle bazında standart hesabı yapıldığında ise, mahallelerin \%58,83'lük kesimde sağlık tesisinin yer almadığı, \%31,44'lük kesiminin standartların altında kaldığı ve \%13,71'lik kesiminin standartları sağladığı görülmüştür (Tablo 5). 
Tablo 5. Ankara Çankaya ilçesi mahalle bazlı ikinci basamak sağlık kuruluşlarına ilişkin standart dağılımı (Kaynak: Çankaya Belediyesi ve Türkiye İstatistik Kurumu (TÜİK) Adrese Dayalı Nüfus Kayıt Sistemi (ADNKS) verileri kullanılarak yazarlar tarafından oluşturulmuştur.)

\begin{tabular}{lrr}
\hline Standartlar (m²/kişi) & Mahalle dağılımı (Adet) & Mahalle dağılımı (\%) \\
\hline $\mathbf{0}$ & 68 & 58,83 \\
$\mathbf{0 , 0 1}-\mathbf{1 , 5 9}$ & 39 & 31,44 \\
$\mathbf{1 , 6 0}-\mathbf{1 4 , 9 9}$ & 12 & 9,69 \\
$\mathbf{1 5 , 0 0}-\mathbf{6 5 , 0 0}$ & 5 & 4,02 \\
\hline Toplam & $\mathbf{1 2 4}$ & $\mathbf{1 0 0}$ \\
\hline
\end{tabular}

Sağlık tesisi alanlarının bulunmadığı Çankaya İçcesinin kırsal mahallelerinden olan Yakupabdal, Tohumlar, Kömürcü, Evciler, Karahasanll, Çavuşlu, Yayla ve Akarlar'da henüz imar planlarının olmadığı ve bu mahallerde yaşayan mahalle sakinlerinin çevre mahallelerde veya çevre ilçelerde yer alan sağlık tesisi alanlarına erişim sağladıkları saptanmıştır.

Çankaya ilçesinde Ankara ilinin merkezi iş alanı etkinliklerinin en yoğun olarak gerçekleştiği mahaller olan Kültür, Kızılay, Devlet, Kocatepe, Maltepe, Bahçelievler, Kavaklıdere, Çankaya, Ayrancı, Öveçler, Balgat, Çukurambar, Gaziosmanpaşa, Seyran, Söğütözü, İncesu ve Cebeci mahallelerinde yer alan sağlık tesisi alanlarının ise imar planlarında merkezi iş alanı ve ticaret alanı kullanımında kaldığı anlaşılmıştır.

Sağlık tesisi alanlarının standartların üzerinde olduğu yeni yerleşim bölgeleri olan İmrahor, Dodurga, Ahlatlıbel, Yeşilkent ve Karataş mahallelerinde ise nüfusun az olduğu ancak yer seçimi yapılan sağlık tesisi alanlarının fazlalığı dikkat çekmiştir (Şekil 4). Bu mahallelerde sağlık tesisi alanlarının fazla gözükmesinin nedeni imar planlarında sağlık alanlarının bulunması, ancak söz konusu mahallelerde yapılaşma tamamlanmadığı için alanda yer alması gereken toplam nüfusun henüz mahalleye yerleşmemiş olmasıdır (Şekil 4). 


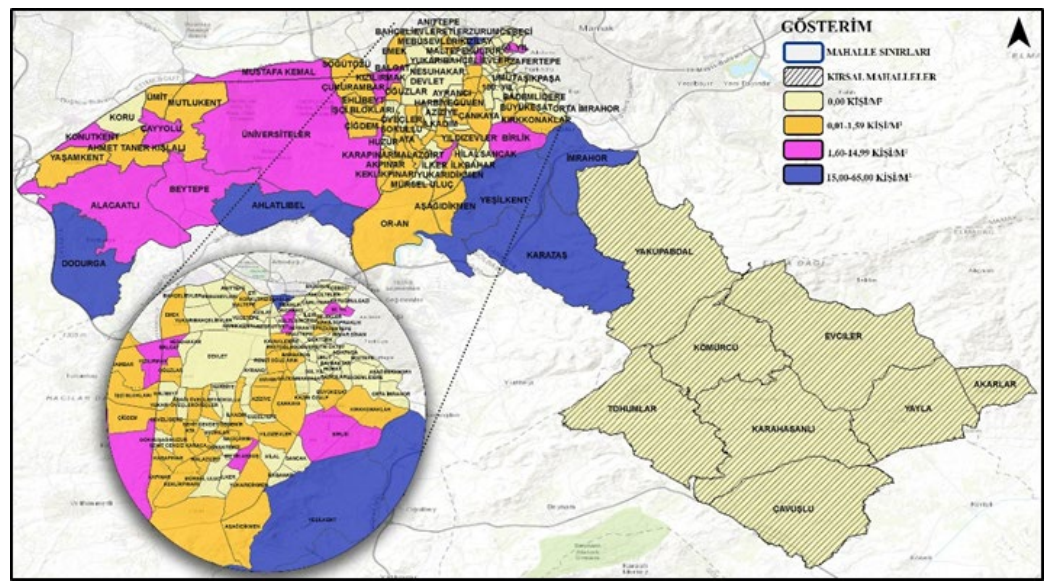

Şekil 4. Çankaya ilçesi mahalle bazlı ikinci basamak sağlık kuruluşları dağılımı (Kaynak: Çankaya Belediyesi verileri kullanılarak yazarlar tarafından oluşturulmuştur.)

Pandemi sürecinde sağlık hizmetlerini sağlanması ve sunulmasına yönelik olarak Çankaya ilçesindeki sağlık tesis alanlarına yönelik olarak yapılan analizler sonucunda 2020 yılı Çankaya ilçesi mevcut arazi kullanımı ile yürürlükteki imar planları arasında farklılıklar olduğu saptanmıştır. 2020 yılı arazi kullanımına bakıldığında yürürlükteki imar planlarında yer alan sağlık tesis alanlarının sadece $\% 42,52$ 'sinin inşaatının tamamlanıp hizmet verdiği, geriye kalan $\% 57,48$ 'sinin henüz inşaatının tamamlanmadığı tespit edilmiştir (Şekil 5). Bu tespitler sonucunda 2020 yılında Çankaya ilçesinde hizmet veren sağlık tesisi alanlarında kişi başına düşen $\mathrm{m}^{2}$ 0,63'dür (Tablo 6).

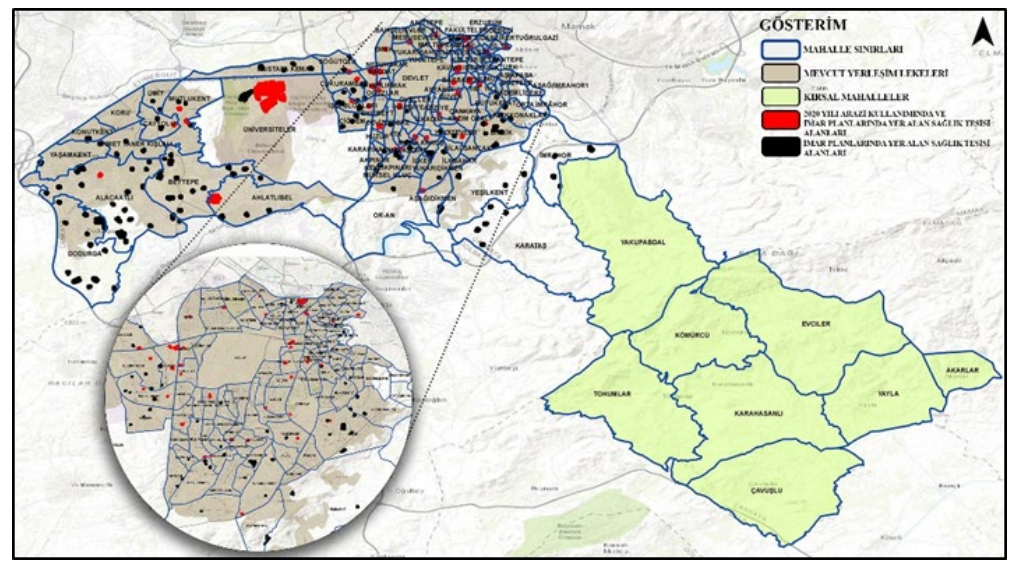

Şekil 5. Çankaya ilçesi 2020 yılı arazi kullanımına ve imar planlarına göre sağlık tesislerinin durumu (Kaynak: Çankaya Belediyesi ve 2020 yll arazi kullanım verileri kullanılarak yazarlar tarafindan oluşturulmuştur.) 
Tablo 6. 2020 yılı itibari ile Ankara Çankaya ilçesinde hizmet veren ikinci basamak sağlık kuruluşlarına ilişkin standartlar (Kaynak: Çankaya Belediyesi ve Türkiye İstatistik Kurumu (TÜIKK) Adrese Dayalı Nüfus Kayıt Sistemi (ADNKS) verileri kullanılarak yazarlar tarafından oluşturulmuştur.)

\begin{tabular}{lllll}
\hline $\begin{array}{l}\mathbf{2 0 1 9} \text { Yılı Çan- } \\
\text { kaya İlçesi } \\
\text { Nüfusu }\end{array}$ & $\begin{array}{l}\text { Çankaya İlçesi } \\
\text { Sağlık Alanları } \\
\left.\mathbf{( M}^{2}\right)\end{array}$ & $\begin{array}{l}\text { Çankaya İl- } \\
\text { çesinde } \\
\text { Hizmet Ve- } \\
\text { ren Alanları }\end{array}$ & $\begin{array}{l}\text { Çankaya } \\
\text { İlçesinde Hizmet } \\
\text { Veren Sağlık Alan- } \\
\text { ları (M²/Kişi) }\end{array}$ & $\begin{array}{l}\text { Standart } \\
\mathbf{( M}^{2} / \text { Kişi) }\end{array}$ \\
\hline 944609 & 1396669,11 & 593960,89 & 0,63 & 1.60 \\
\hline
\end{tabular}

\section{Üçüncü Basamak Sağlik Kuruluşları ve Sağlik Kampüsleri}

2019 yılında Sağlık Bakanlığı Sağlık Hizmetleri Genel Müdürlüğü tarafından yayınlanan genelgeye göre üu̧üncü basamak sağlık kurumları, ileri tetkik ve özel tedavi gerektiren hastalıklar için yüksek teknoloji içeren eğitim ve araştırma hizmetlerinin yapıldığ 1 kurumlardır.

Çankaya ilçesi sinurları içerisinde üçüncü basamak sağlık kuruluşu olduğu tespit edilen 2 hastane yer almaktadır (Şekil 6). Kapalı alanlara ilişkin yapılan analizlerden Başkent Üniversitesi Ankara Hastanesi'nin standartlara göre asgari büyüklüğü karşılamadığı görülmektedir. Ufuk Üniversitesi Dr. Rıdvan Ege Hastanesi ile ilgili olarak da kapalı alan bilgisine ulaşılamadığından karşılaştırma yapılamamıştır (Tablo 7).

Tablo 7. Ankara Çankaya ilçesi üçüncü basamak sağlık kuruluşlarına ilişkin standartlar (Kaynak: T.C. Sağlık Bakanlığı verileri kullanılarak yazarlar tarafından oluşturulmuştur.)

\begin{tabular}{lrrr}
\hline $\begin{array}{l}\text { Üçüncü Basamak Sağlık Ku- } \\
\text { ruluşları }\end{array}$ & $\begin{array}{r}\text { Yatak } \\
\text { Sayısı }\end{array}$ & $\begin{array}{r}\text { Sağlık Alanları } \\
\left.\mathbf{( M}^{2}\right)\end{array}$ & $\begin{array}{r}\text { Olması Gereken As- } \\
\text { gari Alan (M2) }\end{array}$ \\
\hline $\begin{array}{l}\text { Ufuk Üniversitesi Dr. Rıdvan } \\
\begin{array}{l}\text { Ege Hastanesi } \\
\text { Başkent Üniversitesi Ankara }\end{array}\end{array}$ & 221 & - & 28.730 \\
Hastanesi & 340 & 20.000 & 44.200 \\
\hline
\end{tabular}

Türkiye'de Sağlık Bakanlığı'nca belirlenen sağlık hizmet sınıflarının dışında entegre sağlık kampüsleri de hizmet vermektedir. Şehir hastaneleri olarak bilinen bu kurumlar Kamu Özel Ortaklığı modeli ile hayata geçirilmektedir (Cerrahoğlu, 2016). Türkiye'de sözleşmesi imzalanan 18 şehir hastanesinden 12'si hizmete geçmiş durumdadır (T.C Sağlık Bakanlığı Sağlık Yatırımları Genel Müdürlüğü, 2020). Hizmet veren şehir hastanelerinden Ankara Bilkent Şehir Hastanesi Çankaya ilçesi sınırları içerisinde yer almaktadır (Şekil 6).

2019 yılında hizmet vermeye başlayan ve pandemi döneminde pandemi hastanesi olarak tanımlanmış Ankara Bilkent Şehir Hastanesi yüksek teknoloji altyapısına sahip olup 3810 yataklıdır. 723 yoğun bakıma sahip olan şehir has- 
tanesi, olağanüstü bir durum karşısında yoğun bakım ünitelerini 2.000'e çıkarabilecek kapasiteye sahiptir. İzolasyonun önemli olduğu Covid-19 sürecinde gerekli prosedürleri uygulayacak altyapıya sahip olan şehir hastanesi ayrica teşhis prosedürü ve tanı alan hastalara uygulanan tedavilerde ileri tetkik hizmeti vermektedir (Ankara Şehir Hastanemiz'de Kovid-19'la mücadele, teşhis ve tedavi süreçleri, 2020).

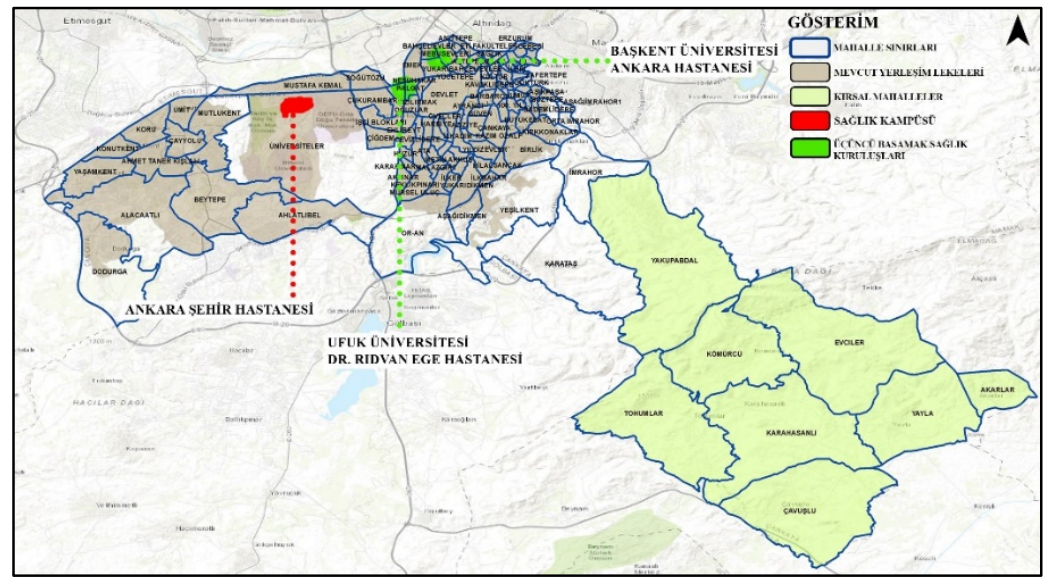

Şekil 6. Çankaya ilçesi üçüncü basamak sağlık kuruluşları

(Kaynak: Çankaya Belediyesi verileri kullanılarak yazarlar tarafından oluşturulmuştur.)

\section{Tartışma ve Sonuç}

Dünya Sağlık Örgütü'ne göre, bir ülkenin sağlık sistemi, herkese gerekli olan sağlık hizmetinin yüksek kalitede verilmesini sağlayacak şekilde tasarlanmalıdır ve her ülke bu faktörleri göz önünde tutarak kendi özgün sağlık sistemini geliştirmelidir. Ulusal sağlık politikaları belirlenirken toplumun sosyo-ekonomik yapısı ve demografik yapısı; kurumların finansmanı ve sürdürülebilirliği; bireylerin eğitim durumları ve beklentilerinin ve ayrıca çevre politikaları ve teknolojik altyapının da göz önünde bulundurulması gereklidir. Sağlık politikaları düzenlenirken, sağlık hizmetlerinin kimler tarafından üretileceği, nasıl sunulacağı, nasıl finanse edileceği, hizmetin kullanıcılara nasıl ulaştırılacağının bilinmesi önemlidir. Bu bağlamda alınan kararlar yasal dayanaklara göre belirlenmelidir (Aykır, 2014). Türkiye'de sağlık sistemi sunumunda her ne kadar yetkili kuruluş Sağlık Bakanlığı olsa da mekânsal olarak işlevlerin yer seçimine yönelik yapılan imar planları ve uygulanan standartlar süreçte önemli rol oynamaktadır.

Covid-19 pandemisi küresel düzeyde temel sağlık hizmetlerinin sunumunun sürdürülebilirliği konusunda büyük etkiye sahip olmuştur. Dünyanın 
dört bir yanındaki sağlık sistemleri, artan Covid-19 hastalarına yönelik talep karşısında zorlanmaktadır. Özellikle bu süreçte engelliler, çocuklar, yaşlılar, kronik hastalıklarla yaşayan insanlar gibi en savunmasız nüfuslar için önleyici ve iyileștirici hizmetlerin sürdürülmesi kritik öneme sahiptir (World Health Organization maintaining essential health services during the Covid-19 outbreak, 2020) .

Pandemi sürecinde kentsel sağlık yaklaşımının üçüncü odağı olan şehirlerde sağlık hizmetleri sunumu önem kazanmıştır. Hizmetlerin sunumu her ne kadar ülkeler arasında değişkenlik gösterse de ortak özelliği adaletsiz erişimi engellemek ve şehirleri sağlık tehditlerine karşı dayanıklı hale getirmektir. Özellikle sağlık sistemine yapılan yatırımlar ve bu yatırımların yer seçimi ve niteliği, hizmetin erişimi ve yönetimi açısından önem teşkil etmektedir.

Ankara-Çankaya İçesinde yer alan sağlık hizmet alanlarının mekânsal yer seçimi kararlarının çeşitli boyutlarıyla analiz edildiği bu çalışmada;

- Birinci Basamak Sağlık Hizmetleri sunumunda;

○ özellikle aile sağllğ 1 merkezlerinin \% 93,22' lik kesiminin konut alanı, ticaret alanı, belediye hizmet alanı, pazar alanı gibi kullanımların içinde yer aldığı, bu nedenle planlar ile kullanımlar arasında uyumsuzluk olduğu,

- yerleşimlerini tamamlamış olan mahallelerde erişilebilirlik sağlanırken, bu hizmetlerin konut alanında bağımsız birimler içerisinde yer almasından dolayı asgari birim alanı sağlayamadığı,

- henüz gelişmekte olan ancak nüfus yoğunluğu da bir o kadar fazla mahallelerde, hem asgari birim alan, hem de erişebilirlik açısından yetersizlikler yaşandığı,

- İkinci Basamak Sağlık Hizmetleri sunumunda;

- arazi kullanımı ile yürürlükteki imar planları arasında hem plan kararları, hem de uygulamalar açısından farklılıklar olduğu,

- belirli mahallelerde standartların üzerinde yığılmaların olduğu, buna karşı belirli mahallelerde yeterli düzeyde hizmete ulaşılamadiğı,

○ ulusal ve uluslararası özel hastanelerin (Memorial Ankara Hastanesi, Medicana Sağlık Grup, Liv Hospital, HC International Clinic...) ilçenin prestijli bölgelerinde yer seçtiği, bunun da mekânsal olarak eşitsizlikler ve dengesizlikler yarattı̆ı,

- Üçüncü Basamak Sağlik Hizmetleri sunumunda; 
○ Çankaya İlçesinin Ankara'nın merkez ilçesi olması nedeniyle tüm kente hitap eden üçüncü basamak sağllk kuruluşların bu ilçede yer aldığı,

- Üçüncü basamak sağlık kuruluşlarına bağlı ikinci basamak sağlık kuruluşlarının (semt poliklinikleri) da genellikle bu ilçede yer seçtiği, ancak bu durumun imar planlarında verilen kararlarla örtüşmediği,

○ Çankaya İlçesinin Bilkent Entegre Sağlık Kampüsü'nün kurulmasiyla tüm kente hatta çevre illere hizmet verdiği,

anlaşılmaktadır.

Çankaya ilçesinin sağlık tesisi mekânsal yer seçiminde Sağlık Bakanlığı tarafından belirlenen sağlık kurum/kuruluş basamakları ile imar planlarının uygulama aracı olan Mekansal Planlar Yapım Yönetmeliği ve Planlı Alanlar İmar Yönetmeliği'nin tam olarak birbirleri ile örtüşmediği tespit edilmiştir. Böyle bir ikilemin varlığ genel anlamda sağlık hizmetlerinin sunumunda karmaşıklığa sebebiyet vermektedir. Covid-19 pandemisi özelinde sağlık hizmetleri sunumu değerlendirildiğinde, bu dönemde ikinci ve üçüncü basamak sağlık hizmetlerinin yükünü azaltan birinci basamak sağlık hizmetlerinin ilçenin doğusunda mekânsal olarak daha erişilebilir olduğu görülmektedir. Ancak insanların birbiri ile olan temasın en aza indirilmesinin önem arz ettiği bu süreçte diğer kullanımlardan bağımsız sağlık tesisleri alanlarının oluşturulmasının da gerekliliği bir kez daha ortaya çıkmaktadır. Çankaya ilçesi örneğinde aile sağlığı merkezlerinin büyük çoğunluğunun konutlarla iç içe yer alması halk sağlı̆̆ının korunması açısından bir tehdit unsuru olarak tanımlanmaktadır. İkinci ve üçüncü basamak sağlık hizmetlerine yönelik olarak ise, tüm kente hizmet veren şehir hastanesinin ilçede yer alması sağlık hizmetleri açısından ilçeyi odak haline getirmekte ve çeşitli bölgelerden gelen nüfusun bu bölgede yoğunlaşmasına neden olmaktadır. Pandemi gibi olağan üstü durumlardaki tecrübeler de göz önüne alınarak, sağlık hizmetlerinin yer seçiminde bölgenin sosyal ve demografik özellikleri yanı sıra etki alanları, hizmet kapasitesi ve yaya ve araç ile erişilebilirliği gibi kriterler göz önüne alınarak sağlık alanlarının yeniden organize edilmesi gerekmektedir. 


\title{
Extended Abstract
}

\section{Assessment of Spatial Location of Health Care Services of Urban Health and Covid-19: \\ The Case of Ankara-Çankaya District}

\author{
Emine Şeyda Satılmış \\ İrem Akkaya \\ Çiğdem Varol \\ Büyükcivelek \\ ORCID: 0000-0002-2573-2318 \\ ORCID: 0000-0003-2840-0578 \\ ORCID: 0000-0002-2432-5745
}

Epidemics such as Ebola, SARS, MERS had aroused in the current century, but contrary to COVID-19, they lost their effectiveness before they reached to global scale. Covid-19 has turned into a global epidemic, and reached a level that threatens all humanity. The provision of services, one of the three main focal points of the urban health approach, has gained importance in urban areas with the global pandemic. Although the content of healthcare services varies due to countries, their common aim is to increase the accessibility to services and to make cities resilient to health threats. Investments in healthcare facilities, decisions on their site selection and their qualification are considered to be important for increasing the accessibility to facilities and to make their management better. This study aims to analyse the provision of health services in Cankaya district of Ankara focusing on the spatial standards and location decisions regarding Covid-19 pandemic.

According to the World Health Organization (WHO), in the 21st century, urbanization has a significant impact on health. From a health perspective, in relation with the rising urban population, increasing urban problems will expose cities to a health burden in the future. Various concepts, approaches and policies are being developed in order to identify and find solutions to health problems that cities face with the increasing urbanization. One of these approaches is the urban health approach, which has first emerged in the mid1980s. Today, it is a multidisciplinary field of study including researches on 
the health of the urban population. There are three main focal points of urban health. These focal points are urban health problems and their distribution in the population, a hygienic environment and its effects, and how services are delivered in the urban space.

The Republic of Turkey Ministry of Health is the competent authority for the provision of health services in Turkey. Ministries, municipalities and investors play a role in the provision of health services. Health services are classified by the Ministry of Health under three main headings as preventive, curative and rehabilitative services. These services are provided via primary healthcare services, secondary healthcare services and tertiary healthcare services. Besides, integrated health campuses built by public-private partnerships are top-tier healthcare units provided by the Ministry of Health.

In Turkey, the adequacy and accessibility of health services in urban areas are determined according to the standards in the Spatial Plans Construction Regulation. Health service areas in spatial plans of all types and scales are divided into eight groups, and minimum unit areas are determined according to healthcare facilities. In addition to the minimum unit areas, the minimum square meters per person varies according to the population size of the settlement. Accessibility to healthcare facilities is defined by walking distances, which is determined as 500 meters for family health centers only.

At the beginning of Covid-19 pandemic, the provision of health services was carried out jointly with national and international institutions and organizations under the coordination of the Ministry of Health. These works included measures to prevent the spread of the disease and to support treatment in Turkey. Within this context, travel restrictions were imposed throughout the country at certain times, education was suspended and distance education was started, lockdown measures put into force, and further restrictions were imposed on risky age groups. During this period, decisions were taken regarding the management and operation of health services. Operation centers for Covid-19 were established and filiation and contact tracing was carried out by teams to follow-up the disease. In terms of public health, wearing a mask became compulsory across the country.

Ankara was selected as the study area regarding the highly increasing trend in the number of patients after the social and economic normalization period in June 2020. The factors in the selection of Cankaya district were that Cankaya was the most populous central district of Ankara where the public institutions and organizations, important commercial areas and public trans- 
portation routes were in the district, all of which created a high risk of transmission of Covid-19 due to mobility potential. Besides many hospitals, including the Ankara City Hospital in the district were declared to be pandemic hospitals by the Ministry of Health. A two-stage method was followed in the study to discuss the provision of health services in Cankaya district. Firstly, the data regarding the spatial location decisions of the health service areas were obtained from the relevant institutions and organizations. Secondly, health institutions and organizations that provide active services according to the system specified in the circular issued by The Republic of Turkey Ministry of Health General Directorate of Health Services in 2019 during the Covid-19 process were analyzed. In the analysis, the competence of health services at different levels with the standards determined within the scope of the laws and their accessibility according to the demographic characteristics of the region were analyzed through using geographic information systems.

As a result of the study, it was determined that the spatial location selection of healthcare services in Cankaya district was different which healthcare services provisioned by the Ministry of Health and regulations for spatial plans. Considering the provision of healthcare services, it was revealed that primary healthcare services that aimed to reduce the burden of secondary and tertiary healthcare services were spatially more accessible in the eastern parts of the district. As minimizing the contact between people appeared to be important in the Covid-19 pandemic process, the location of health facilities areas should be distant from other uses. In the example of Cankaya district, the fact that most of the family health centers being together with residences was defined as a threat to the protection of public health. Regarding secondary and tertiary health services, the location of the city hospital serving the whole city in the district had made the district a focus in terms of health services and caused mobility the population from various regions towards this region. Consequently, the experiences of unusual situations such as Covid-19 pandemics show that the location of healthcare services areas should be reorganized by considering the social and demographic characteristics of the region as well as the impact area and the service capacity of healthcare services and accessibility of them by pedestrians and vehicles. 


\section{Kaynakça/References}

Covid-19 haber geçmişi (t.y). Anadolu Ajansı. 20.02.2021 tarihinde https://www.aa.com.tr/tr/search/?s=koronavir\%C3\%BCs_adresinden erişildi.

Ankara Şehir Hastahanesi. (t.y). Ankara Şehir Hastanemiz 'de Kovid-19'la mücadele, teşhis ve tedavi süreçleri. 10.12.2020 tarihinde https://ankarasehir.saglik.gov.tr/TR,450090/ankara-sehir-hastanemizde-kovid-19la-mucadeleteshis-vetedavi-surecleri.html_adresinden erişildi.

Aykır, E. (2014). 2002-2012 Sağlık Politikaları ve Sağlıkta Dönüşüm. Yüksek lisans tezi. https://tezarsivi.com/2002-2012-saglik-politikalari-ve-saglikta-donusum adresinden erişildi.

BM Ekonomik, Sosyal ve Kültürel Haklar Sözleşmesi (1976, 3 Ocak) BM Genel Kurul Kararı (Sayı:2200A (XXI)) https://www.ohchr.org/EN/ProfessionalInterest/Pages/CESCR.aspx adresinden erişildi.

Boyce, M. R., ve Katz, R. (2020). Rapid urban health security assessment tool: A new resource for evaluating local-level public health preparedness. BMJ Global Health, 5(6), doi:10.1136/bmjgh-2020-002606

Cerrahoğlu, A. (2016).Şehir hastaneleri ve birinci basamak. The Journal of Turkish Family Physician 7(3), 81-84.

Cumhurbaşkanlığı Teşkilatı Hakkında Cumhurbaşkanlığg Kararnamesi. (2018, 10 Temmuz). Resmi Gazete (Sayı: 30474) https://www.mevzuat.gov.tr/MevzuatMetin/19.5.1.pdf adresinden erişildi.

Diez R., A. V., Barrientos-Gutierrez, T., Caiaffa, W. T., Miranda, J. J., Rodriguez, D., Sarmiento, O. L., ve Vergara, A. V. (2020). Urban health and health equity in Latin American cities: What Covid-19 is teaching us. City $\mathcal{E}$ Health Special Issue: COVID-19.

Galea, S., ve Vlahov, D. (2005). Handbook of urban health populations methods and practice, 1-15. https://www.springer.com/gp/book/9780387239941\#reviews_adresinden erişildi.

Galea, S., ve Vlahov, D. (2005). Urban health: evidence, challenges, and directions. Annual Review of Public Health, 26, 341-365. doi:10.1146/annurev.publhealth.26.021304.144708

Gatzweiler, F., Fu, B., Rozenblat, C., Su, H. J., Luginaah, I., Corburn, J., Boufford, J. I., Valdes, J. V., Nguendo-Yongsi, B., Howden-Chapman, P., Singh, R. B., Cooper, R., Oni, T., ve Zhu, Y. (2020). COVID-19 reveals the systemic nature of urban health globally. City $\mathcal{E}$ Health Special Issue: COVID-19. do1:10.1080/23748834.2020.1763761

Glouberman, S., Gemar, M., Campsie, P., Miller, G., Armstrong, J., Newman, C., Siotis, A., ve Groff, P. (2006). A framework for improving health in cities: a discussion paper. Journal of Urban Health : Bulletin of the New York Academy of Medicine, 83(2), 325-338. doi:10.1007/s11524-006-9034-9 
Harpham, T., ve Molyneux, C. (2001). Urban health in developing countries: a review. Progress in Development Studies, 1(2), 113-137. doi:10.1177/146499340100100202

Kelly H., (2011). The classical definition of a pandemic is not elusive. Bulletin of The World Health Organization 89, 540-541

Mekansal Planlar Yapım Yönetmeliği. (2014, 14 Haziran). Resmi Gazete (Sayı: 29030). https://www.resmigazete.gov.tr/eskiler/2014/06/20140614-2.htm adresinden erişildi.

Öztürk, O., ve Karcıŏlu, Ö., (2020). Covid-19 pandemisi sürecinde kamu hastaneleri. Türk Tabipler Birliği Covid-19 Pandemisi Altıncı Ay Değerlendirme Raporu. 10.12.2020 tarihinde https:/www.ttb.org.tr/kutuphane/covid19-rapor_6/covid19 rapor_6_Part26.pdf adresinden erişildi

Rosenberg C. E. (1989). What is an epidemic? AIDS in historical perspective. Daedalus, 1-17.

Samanc1, V . (2020). Birinci basamak sağl1k hizmetleri ve pandemi süreci. Konuralp Medical Journal, Pandemi Deneyimleri, 390-392 . doi: 10.18521/ktd.753605

Schroeder S. A. (1998). Urban health care: what works and why. Journal of Urban Health: Bulletin of the New York Academy of Medicine, 75(2), 349-355. doi:10.1007/BF02345102

Sağlık Bakanlığı. (t.y). T.C. Covid-19 bilgilendirme platformu Covid-19 sözlüğ̈̈. 19 Şubat 2021 tarihinde https://covid19.saglik.gov.tr/TR-66507/s.html adresinden erişildi.

Sağlık Bakanlığı (t.y). T.C. Sağhlk Bakanlı̆̆ı Halk Sağhı̆̆ı Genel Müdürlü̆g̈̈̈ Aile Hekimliği Dairesi Başkanlığı. Aile hekimliği tanımı. 06.11.2020 tarihinde https://hsgm.saglik.gov.tr/tr/ailehekimligi/aile-hekiminin-tan\%C4\%B1m\%C4\%B1.html adresinden erişildi.

T.C. Sağlık Bakanlığı Sağlık Hizmetleri Genel Müdürlüğü Hukuk ve Mevzuat Dairesi Başkanlığı (t.y). 2019/10 Sayılı Genelge (2019, 31 Mayıs) https://shgm.saglik.gov.tr/TR,55587/201910-saglik-hizmeti-sunucularinin-basamaklandirilmasi-hakkinda-genelge.html adresinden erişildi.

T.C. Sağlık Bakanlığı Sağlık Yatırımları Genel Müdürlüğü. (t.y). Şehir Hastaneleri. 06.11.2020 tarihinde https://sygm.saglik.gov.tr/TR,33960/sehir-hastaneleri.html adresinden erişildi.

Türkiye Cumhuriyeti Anayasası (1982,18 Ekim). Resmi Gazete (Sayı: 17863 -(Mükerrer)). https://www.mevzuat.gov.tr/MevzuatMetin/1.5.2709.pdf adresinden erişildi.

Türkiye İstatistik Kurumu. (t.y). Adrese Dayalı Kayıt Sistemi. İstatistiksel tablolar 06.11.2020 tarihinde https://data.tuik.gov.tr/Bulten/Index?p=Adrese-DayaliNufus-Kayit-Sistemi-Sonuclari-2020-37210 adresinden erişildi.

World Health Organization (t.y). Maintaining Essential Health Services During The COVID-19 Outbreak. 06.11.2020 tarihinde https://www.who.int/emergencies/diseases/novel-coronavirus-2019/related-health-issues adresinden erişildi. 
World Health Organization Regional Office for Europe. (t.y). The WHO European Healthy Cities Network: a Response to the COVID-19 Pandemic Close to the People. 19.09.2020 tarihinde https://www.euro.who.int/en/health-topics/environmentand-health/urban-health/who-european-healthy-cities-network/the-who-european-healthy-cities-network-a-response-to-the-covid-19-pandemic-close-tothe-people adresinden erişildi.

World Health Organization. (t.y). Urban Health. 19.09.2020 tarihinde https://www.who.int/health-topics/urban-health adresinden erişildi.

Yücesan, B, ve Özkan, Ö . (2020). COVID 19 pandemi sürecinin sağlık yönetimi açısından değerlendirilmesi. Avrasya Sağlık Bilimleri Dergisi, COVID-19 Özel Sayı, 134-139. 